\title{
Pathobiology
}

Allory, Y. 90

Barysch, M.J. 61

Bodo, J. 115

Borisch, B. 59

Cervera, P. 76

Culine, S. 90

de la Taille, A. 90

Dummer, R. 61

Fléjou, J.-F. 76

French, L.E. 61
Hoessli, D. 59

Hsi, E.D. 115

Karpova, M.B. 61

Leong, A.S.-Y. 99

Schönewolf, N. 61

Zhuang, Z. 99

Zipser, M.C. 61

\section{Subject Index Vol. 78, No. 2, 2011}

Basal cell carcinoma 61

Biomarkers 99

Breast cancer 99

Colon cancer 76

Drug discovery 99

Gastrointestinal cancer 76

Hematopathology 115

HIF 90

Immunofluorescence 115

Immunohistochemistry 99, 115

Melanoma 61

Molecular abnormalities 61

- pathology 76

- technology 99

mTOR 90
Phosphoprotein 115

Predictive markers 99

Prognosis 99

Proteomics 99

Quantification 115

Quantum dots 115

Renal cell carcinoma 90

Skin cancer 61

Squamous cell carcinoma 61

Stem cells 99

Targeted therapy $61,76,90$

VEGF 90

VHL 90

๑) 2011 S. Karger AG, Basel 